\title{
Konzervatívnak lenni az internet korában
}

Ha nem pusztán újításokkal szembeni ösztönös ellenszenvet, vagy elmúlt, személyünkben általában meg sem élt, sőt valójában soha nem is létezett korok iránti nosztalgiát értünk rajta, úgy a konzervativizmusnak a megőrzés funkcionális elméletét kell alkotnia spontán avagy szándékolt társadalmi változások közepette. A tanulmány szerzője mai életvilágunk bizonyos olyan elemeinek szükségessége és ezzel megőrzésre méltó volta mellett érvel, amelyek fenyegetettek a globális számítógépes hálózottság, vagyis egy új kommunikációs technológia uralkodóvá válása által, miközben ezeket az elemeket hosszabb távon voltaképpen az új technológia sem tudja nélkülözni. Azonban a szó szoros értelmében vett hagyományok ma sem nem lehetségesek, sem nem kívánatosak. A szerző alternatív vonatkoztatási keretet javasol: nem hagyományok, hanem olyan specifikus stabilitások keretét, amelyeket a hálózott kommunikáció specifikus illékonyságaival/virtualitásaival szemben artikulál. Ezek a stabilitások: valódi helyek/helységek, változatlan dokumentumok, személyes kapcsolatok.

Kulcsszavak: konzervativizmus, hagyomany, kommunikációs technológiák, másodlagos szóbeliség, internet, stabilitások

\section{Szerzői információ:}

\section{Nyíri Kristóf}

Filozófus 1993-tól az MTA tagja. 1995 és 2005 között az MTA Filozófiai Kutatóintézetének igazgatója. Számos publikációja jelent meg magyarul, németül és angolul a modern filozófiatörténet, az osztrák-magyar eszmetörténet, a nyelvfilozófia és a társadalomfilozófia köréból. Újabb kutatásai a kommunikáció technológiájának történetéhez kapcsolódó filozófiai kérdésekre összpontosulnak. 1997 óta virtuális egyetemi programokat szervez, 2001 januárja óta „A21. század kommunikációja „ címú interdiszciplináris társadalomtudományi kutatási program vezetôje. Néhány fontosabb magyar nyelvû́ publikációja: Európa szélén: eszmetörténeti vázlatok (1986); Hálózat és tudásegész (in A századvég szellemi körképe. Szerk. Sándor Iván. 1995); Globális társadalom, helyi kultúra: Filozófiai vázlat (in Információs társadalom. Szerk. Glatz Ferenc. 2000); Az MMS képfilozófiájához (in Mobilközösség - mobilmegismerés: Tanulmányok. Szerk. Nyíri Kristóf. 2002).

Honlap: www.hunfi.hu/nyiri

E-mail: knyiri@t-email.hu.

Így hivatkozzon erre a cikkre:

Nyíri Kristóf. „Konzervatívnak lenni az internet korában”.

Információs Társadalom VI, 4. szám (2006): 9-17. https://dx.doi.org/10.22503/inftars.VI.2006.4.2

A folyóiratban közölt müvek

a Creative Commons Nevezd meg! - Ne add el! - Így add tovább! 4.0

Nemzetközi Licenc feltételeinek megfelelöen használhatók. 


\section{Konzervatívnak lenni az internet korában*}

Ha nem pusztán újításokkal szembeni ösztönös ellenszenvet, vagy elmúlt, személyünkben általában meg sem élt, sốt valójában soha nem is létezett korok iránti nosztalgiát értünk rajta, akkor a konzervativizmusnak a megór tenie spontán avagy szándékolt társadalmi változások közepette. Ebben a szellemben definiálta Gerd-Klaus Kaltenbrunner a konzervativizmust „az ép intézmények és katasztrófamentes szociális átalakulás feltételei felismerésének, miközben annak anyagát, ami éppen intézményes vagy átalakul, a konkrét történeti helyzet adja”. ${ }^{1}$ Ebben az szellemben vélte Robert Musil, hogy csak ha teremtőek vagyunk, szabad konzervatívnak lennünk; ${ }^{2}$ hogy a gyógyulást nem kereshetjük úgy, hogy hátratekintünk. A kötelékeiktól megszabadult embernek, írja Musil 1923-ban A német ember mint szimptóma címú esszéjében, a régi kötelékeket ajánlják: „Hit, tudományelóttiség, egyszerúség, humanizmus, altruizmus, nemzeti szolidaritás, állampolgári alávetettség: a kapitalista individualizmusnak és mentalitásának feláldozása. [...] Azt hiszik, hogy hanyatlást kell gyógyítaniok. - Egészen ritkán döbbennek rá, hogy ezek a jelenségek új problémát jelentenek, amely még nincs megoldva. Alig ismerek olyan feldolgozást, amely a jelennek ezt a problematikáját egyszer mint problémát, mint valami újat fogná fel, és nem mint elhibázott megoldást." 3 És ebben a szellemben utalt Hermann Lübbe 1983-ban a

* Jelen szöveg annak a német nyelvû́ clôadásomnak a fordítása, amely a Collegium Budapest 1999. jún. 28-29-én rendezett konferenciáján hangzott el. Az eredeti szöveg megjelent Vernetztes Wissen: Philosophie im Zeitalter des Internets címú kötetemben (Wien, 2004, Passagen Verlag).

Előadásom egyfajta visszatérést jelentett ahhoz a beállítottsághoz, amelynek megfogalmazására először „Wittgenstein új tradicionalizmusa „ címú esszémben (Világosság, 1975/10.) tettem kísérletet, és amelyet még 1986-87-ben is képviseltem, első Alexander von Humboldt ösztöndíjas tartózkodásom során a Ruhr-Universität Bochumon. 1990-91-ben, ugyanott, második AvH-ösztöndíjas idốszakom adott alkalmat Tradition and Individuality címú kötetem (Dordrecht, 1992, Kluwer) összeállítására, amely már más irányba mutatott, és nem zárta ki az újbóli váltóállítás lehetôségét. Ahogyan a kötet elốszavában írtam: „Arra a meggyốződésre jutottam, hogy az egyéni, kritikus gondolkodás terét, történetileg és pszichológiailag, az írás közege teremti meg. Ám kétséges, hogy milyen messzire terjed ez a tér; hogy az írott szó milyen mélyen hatja át a társadalmi interakciókat, s hogy vajon a jövóben is megtartja-e azt a szerepet, amellyel most bír. És annak mértékében, ahogy a kommunikáció preliterális marad vagy posztliterálissá válik, a tradicionalizmus problematikája még mindig élő."

${ }^{1}$ Gerd-Klaus Kaltenbrunner: „Der schwierige Konservatismus”. Lásd Kaltenbrunner (szerk.): Rekonstruktion des Konservatismus. Freiburg i. B., 1972, Rombach, 45. o.

${ }^{2}$ Robert Musil: Tagebücher, Aphorismen, Essays und Reden. Szerk. Adolf Frisé. Hamburg, Ro wohlt, 219. o.

${ }^{3}$ Robert Musil: Gesammelte Werke in neun Bänden. Szerk. Adolf Frisé. Reinbek bei Ham burg, 1978, Rowohlt, 8. köt., 1357. és 1382. o. - Vagy ahogyan az 1922-ben írt „Das hilflose Europa „ címú esszéjében olvasható: „Ha azt hirdetik..., hogy korunkból hiányzik a szintézis, vagy a kultúra, vagy a vallásosság, vagy a közösség, akkor ez alig több, mint a "régi szép idók « dicsérete, hiszen senki sem tudná megmondani, hogyan fessen ma a kultúra, vagy a vallás, vagy a közösség, ha a laboratóriumokat és repülőgépeket és a társadalom mamuttestét valóban fel akarjuk venni a szintézisbe, és nem pusztán meghaladottként clőfeltételezzük." (uo., 1087. o.). 
maga konzervatív felfogására: „mivel a hagyományok a dinamikus civilizációkban szúkös javaknak számítanak”, óvatosan kell bánnunk az olyan tradíciókkal, amelyek „még elevenen maradtak”. Lübbe korántsem javasolja, hogy visszanyúljunk immár „,rég föloldódott” hagyományokhoz. Ahogyan írja: „A konzervatív kultúraelmélet kiindulópontja éppen az a felismerés, hogy a társadalmi és kulturális fejlemények dinamikáját kiegészíti a sebesség, amellyel ma a hagyományok elavulnak. Jelen életvilágunk bizonyos résztartományaiban gyorsabban avulnak el, mint amiképp képződni tudnak új tradíciók, vagyis olyan, a tapasztalat próbáját kiállt életformák, amelyek nemzedékeket átívelő érvényességük folytán végül elnyerik a kulturális magától értetôdés státusát." ${ }^{4}$

Mai világunk bizonyos olyan elemeinek funkcionalitása és ezáltal megốrzésre méltó volta mellett szeretnék itt érvelni, amelyeket a globális számítógépes hálózottság, vagyis egy új kommunikációs technológia uralkodóvá válása fenyeget - miközben ezeket az elemeket hosszabb távon voltaképpen az új technológia sem tudja nélkülözni. Ehhez először is Lübbéhez képest valamelyest szúkebbre kell vonnom a hagyomány fogalmának határait. A hálózott kommunikáció és egyáltalán az elektronikus kommunikáció ahhoz a kultúrához tartozik, amelynek jellemzésére a másodlagos szóbeliség megjelölés vált szokásossá. Ez a kultúra, negyedik történeti szakaszként, az elsódleges szóbeliség, az írásbeliség és a könyonyomtatás három szakaszára épül. A kommunikációs technológiák története egyszersmind a társadalmi tudás megórzésének és átadásának a története is. Elsődlegesen szóbeli kultúrákban, melyekben az írás technikája még egyáltalán nem játszik szerepet, vagy csak egészen kezdetleges módon, mint emlékezettámasz aides-mémoire, mint mondjuk az inka csomóírás -, a szó kizárólag mondott és hallott; a társadalmi tudás könnyen memorizálható formulákban, autoritatív szövegek állandó ismétlése, vagyis hagyomány által rögzül. A hagyomány természetéhez tartozik, hogy igazságtartalma nem vonható kétségbe - hiszen a kétely a közönségnek, a hallgatónak éppen azt a teljes odaadását rombolná szét, amely nélkül a hallottak bevésése csak hiányosan mehetne végbe. A közvetített szöveg kétségbevonhatatlanságát a nemzedékról nemzedékre való változatlan továbbadásnak, sốt végsố soron az isteni eredetnek a fikciója törvényesíti, s az ünnepélyesség és ritualitás elemei teszik hangsúlyossá.

A szó szigorú értelmében vett hagyomány tehát nem más, mint a tudásmegốrzés funkcionális intézménye az írásbeliség elő́tti kultúrákban. ${ }^{6}$ A hagyományos tudás mindazonáltal kritikátlan: hiszen az élôszóban átadott szövegek belsố-illetve egymáshoz viszonyított - koherenciája csak nagyon korlátozottan ellenốrizhetô. Ehhez képest az írásbeliség - az a technológia, amely elôször teszi lehetơvé a kimondott szó rögzítését, a különbözố szövegek egybevetését, a kijelentések szigorú azonossága vagy különbsége kérdésének fölvetését - az ellentmondás és a koherencia eszméjéhez, kritikus-racioná-

\footnotetext{
${ }^{4}$ Hermann Lübbe: ,»Neo-Konservative « in der Kritik”. Merkur, 1983/6, 624. sk. o.

${ }^{5}$ Itt mindenekelótt Walter J. Ong munkáját követem: Orali ty and Literacy: The Technologizing of the Word. London, 1982, Methuen. Lásd még Eric Havelock múveit: Pre face to Plato. Cambridge, MA, 1963; The Greek Concept of Jus tice: From Its Shad ow in Homer to Its Substance in Plato. Cambridge, MA, 1978; The Literate Revolu tion in Greece and Its Cultural Consequences. Prince ton, 1982; The Muse Learns to Write: Reflec tions on Orality and Literacy from Antiquity to the Present. New Haven, 1986; valamint Jack Goody és Ian Watt „Consequences of Literacy" címú tanulmányát a Goody által szerkesztett Literacy in Traditional Societies címú kö tetben. Cambridge Univ. Press, 1968.

${ }^{6}$ Részletesebben lásd Nyíri Kristóf: A hagyomány filozófiája. Budapest, 1994, T-Twins.
} 
lis gondolkodáshoz vezet. Ezen új tudat teljes kibontása ugyanakkor a könyvnyomtatás korszakára vár. A kéziratok kora még túlnyomóan szóbeli; az írott szöveg nehézkesen állítható elô és drágán szerezhetố be, s inkább az orális kommunikáció végpontját és új kezdetét jelenti, mintsem hogy helyére lépjen annak. A tipográfia korszaka nemcsak az önálló múvelốdés lehetốségét teremti meg, hanem a könyveknek, a megbízható-azonos textusoknak gazdagságával, standardizált idốrendjeivel és taxonómiáival létrehozza a tendenciájában egységes tudomány és egyáltalán a kumulatív-kritikai tudás eszméjét, a modern történeti tudatot. A könyvnyomtatás korában a hagyomány messzemenôen elveszíti funkcionalitását.

Mármost milyen szerepet játszhatnak a hagyományok a másodlagos szóbeliség és kivált az internet korában? Az internet az információs társadalom gazdaságának, politikájának, tudományának és kultúrájának fokozatosan mindent átfogó és mindent átható kommunikációs közege. Az internet sok-sok tízmillió oldalnyi írott (gyakran képekkel, sốt hangokkal vegyített) dokumentumot tartalmaz. Ezek a dokumentumok nem mindig „épületesek”. Alapvető́en azonban az internet az értékes információk és ismeretek roppant s egyre hatalmasabb tárháza. Egyszersmind a személytól személyhez szóló információk cseréjének is színtere. Feltûnő, hogy az e-mail elterjedése óta a családi és rokoni kapcsolatok, a barátságok, továbbá a személyes kontaktusban létrejött kollegiális kapcsolatok a korábbiaknál sokkal kevésbé szenvedik meg az esetleges fizikai távolságot. S persze sok olyan ismeretség adódik, amely e-mail révén keletkezik, s azután személyes találkozáshoz vezet.

Szembeötlik, hogy az internet írásbelisége a szóbeliség bizonyos vonásait is mutatja. A jellegzetes e-mail stílusában kevésbé a levélre, mint inkább a telefonbeszélgetésre emlékeztet. Ahogyan a bécsi filozófus, Herbert Hrachovec fogalmaz: „Az elektronikus posta... villámgyorsan úton van, s ez a tempó visszahat az íróra. Nem tudják kivárni, hogy az "üzenetet « elküldjék. Számtalan gépelési hiba - hogy a gondolattalanságról ne is beszéljünk - bizonyítja, hogy a gyors folytatás fontosabbnak számít, minthogy idốt szánnának a javításokra. S alighogy az üzenet elment, már archiválva is van, vagyis múlttá lett. [...] A médium permanens aktualitása a tartalom szakadatlan elavulását vonja maga után."7 Itt alá kell húznunk, hogy a digitális szöveg a kézzel írotthoz vagy nyomtatotthoz képest sokkal illékonyabb. Ha a szerzố változtat, a régi szövegrészek nyomtalanul eltúnnek; a szerzố autoritása is elenyészik, hiszen a szöveget bármikor átírhatja az olvasó. A weben fellelhető dokumentumok, hasonlóképpen, csak viszonylagos állandósággal bírnak - s a weboldalak látogatói mindenekelótt a frissített, új információk iránt érdeklődnek.

A hagyományok, mondtuk, a tudásmegốrzés intézményei az írásbeliség elốtti társadalmakban. Sót, többek is annál: ama „mozdulatlan vonatkoztatási kereteket” alkotják - hogy Halbwachs kifejezését alkalmazzuk ${ }^{8}$-, amelyek nélkül a kommunikáció fogalmi szinten egyszerúen lehetetlen. A fogalmi gondolkodás a nyelven alapul; a nyelv pedig, mutatta meg Wittgenstein, az életformák egyezésén - valamint bizonyos meghatározó meggyózódések egyezésén. Ezt az egyezést valami teljesen eredendóként kell elgon-

${ }^{7}$ H. Hrachovec: „Intimität in der Mailbox”, lásd U. M. Ernst, Ch. Annerl és W. Ernst (szerk.): Rationalität, Gefühl und Liebe im Ge schlech ter ver hält nis. Pfaffenweiler, 1995, Centaurus, 44. o.

${ }^{8}$ Maurice Halbwachs: Les cadres sociaux de la mémoire. Paris, 1925, Alcan, 20. o. 
dolnunk, korántsem olyasmiként, amin, mondjuk, vitatkozni lehetne - inkább úgy áll a helyzet, hogy ez az egyezés mindenfajta vita alapja. „Ahhoz, hogy a nyelven keresztül megértsük egymást”, írja Wittgenstein, „nemcsak a definíciókban kell megegyeznünk, hanem (bármily különösen hang zik) ítéleteinkben is". ${ }^{9}$ Már ahhoz, hogy az ember tévedhessen, hangsúlyozza Wittgenstein egyik utolsó aforizmájában, az emberiséggel konformitásban kell ítélnie. ${ }^{10}$ Mint mondja: „Bizonyos tekintélyeket el kell ismernünk ahhoz..., hogy egyáltalán ítélhessünk"; ${ }^{11}$ tekintélyeket, mint például iskolánk ${ }^{12}$ vagy áthagyományozódott világképünk; ${ }^{13}$ alapokat, ${ }^{14}$ amelyekkel szemben minden kétely üres. ${ }^{15}$ Witt genstein „tengelyekról” beszél, amelyeknek , helyben kell marad niok”, tényekról, amelyek „nyel vünk alapjaiba vannak öt vözve”. ${ }^{16}$ Ilyen bizonyosságok alkotják az irányt, mely felé haladva „mintegy találkozóra sietünk a többiekkel". ${ }^{17}$

Mármost Wittgenstein érvei, általánosságban szólva, inkább a tisztán szóbeli, semmint az írott nyelvre vonatkoznak; ${ }^{18}$ és azt állítottuk, hogy a hagyományok az írásbeliség kialakulásával és kivált a könyvnyomtatással messzemenően elveszítik jelentôségüket. A hagyományok állandóságát a nyomtatott szöveg állandósága helyettesíti. Ma azonban éppenséggel a nyomtatott szöveget szorítja ki a digitális dokumentum és az audiovizuális média. Utóbbiak korántsem állandók, sokkal inkább változékonyak, cseppfolyósak és múlandók. Vajon azt jelenti-e ez, hogy az elektronikus hálózottság új világában a hagyományok megint egyszer lehetségessé, kívánatossá vagy szükségessé válhatnak? Válaszom: a szó szoros értelmében a hagyományok ma sem nem lehetségesek, sem nem kívánatosak. Nem lehetségesek, mert olyan nemzedékek közötti viszonyokat feltételeznek és a tekintélyelvûség olyan viszonyaira épülnek, amelyek mai posztmodern világunkban elképzelhetetlenek lennének. És nem kívánatosak, mert a racionális gondolkodás ellenében hatnának. David Riesman volt az, aki már az ezerkilenszázötvenes években felhívta erre a figyelmet. A szóbeli átadás és a mozi közötti párhuzamokat vizsgálva, így írt: „az a távolságtartás és kritikus attitûd, amelyet a könyvek teremtenek meg, nem lehetséges a beszélt szóra alapozott társadalomban. Esetenként újragondolhatunk egy szónoklatot, de nem hallgathatjuk meg visszafelé, és megint elölról, amint azt könyvek olvasásakor tesszük - vagyis az írót oly módon ellenórizhetjük, ahogyan a szónokot vagy a filmkészítốt nem lehet. Az a társadalom, amely csak arra hagyatkozhat, amire az egyének emlékezni tudnak, aligha fogja elkerülhetni a demagóg és a költő fogásait: a rímet, ritmust, dallamot, ismétléseket." ${ }^{19}$ A nyolcvanas évek közepén pedig Milan Kundera arról az úgymond el-

${ }^{9}$ Ludwig Wittgenstein: Filozófiai vizsgálódások. I. rész, 242. §.

${ }^{10}$ Ludwig Wittgenstein, A bizonyosságról, 156. §.

${ }^{11}$ Uo., 493. §.

${ }^{12}$ Uo., 47. és 664. §.

${ }^{13}$ Uo., 94. §.

${ }^{14}$ Uo., 449. \$.

${ }^{15}$ Uo., 312. \$.

${ }^{16}$ Uo., 343. és 558. §.

${ }^{17}$ Ludwig Wittgenstein: Bemerkungen ïber die Grundlagen der Mathe matik Frank furt/M., 1974, Suhrkamp, 195. o.

${ }^{18}$ Lásd „Írásbeliség és a privátnyelv-argumentum” címú tanulmányomat A hagyomány filozófiája címú kötetemben.

${ }^{19}$ David Riesman: The Oral Tradition, the Written Word and the Screen Image. Yellow Springs, Ohio, 1956, Antioch Press, 8. o. 
lenállhatatlan folyamatról beszél, melynek során az elôítéletek és átvett frázisok computerekbe írva s a tömegkommunikáció által terjesztve azzal fenyegetnek, hogy hamarosan minden eredeti gondolatot maga alá gyúrố hatalommá válik, elfojtva ezzel a modern európai kultúra lényegét. ${ }^{20}$ Mindazonáltal: nem kell-e azt mondanunk, hogy az elillanó változatlanságok világában a hagyományok, mégis, szükségesek? A válasz - újra - úgy szól, hogy az állandó, vagy legalább viszonylagosan változatlan vonatkoztatási keretek iránti átélt igény, az olyan keretek iránti igény, amelyekben önazonosságunk, értékeink és preferenciáink lehorgonyozhatók, ne vezessen hagyományokhoz a szó átörökített értelmében. Alternatív vonatkoztatási keretet javaslok: nem hagyományok, hanem olyan specifikus stabilitások keretét, amelyeket a hálózott kommunikáció specifikus illékonyságaival/virtualitásaival szemben artikulálok. Ezek a stabilitások: valódi helyek/helységek; változatlan dokumentumok; személyes kapcsolatok.

Az elsô pont tehát: a lokalitások állandóságának problémája. Szögezzük le mindjárt, hogy a lokális is globálisan konstituált. Utóbbi állítás különösnek túnhet, hiszen „lokális” annyit tesz, mint helyi; s a hely, gondolhatnánk, éppenséggel földrajzilag és fizikailag definiált, nem pedig távoli viszonyoktól meghatározott. A látszat csal. Ha „hely”-en többet értünk, mint a puszta geodéziai koordinátákat, úgy csakhamar belátható, hogy a helyek-helységek társadalmi konstrukciók. A szülőfalu, a kedves kisváros, a szépséges természeti táj: mind emlékekból, ismeretségekból, tevékenységekból és eszményekból épülnek föl. Anyagukhoz persze kövek, folyók stb. is hozzátartoznak; ám valamely ốsi rom építốanyagnak meg múemléknek is fölfogható; s a Dunakanyar aligha maradna ugyanaz a hely, ha ama vitatott erốmúvet ott mégis megvalósítanák. A helyet fogalmilag találkozási pontként, tevékenységi terek, kapcsolatok és eleven viszonyok, befolyások és mozgások érintkezési pontjaként ragadhatjuk meg. Doreen Massey megfogalmazásában: „Ami valamely helynek a maga különösségét kölcsönzi, az... az a tény, hogy meghatározott pontban találkozó s ott egymást keresztezố társadalmi viszonyok egyedi konstellációjából épül föl. [...] A helyeket nem határolt területeknek kell elképzelnünk, hanem társadalmi viszonyok és fölfogások hálózata artikulált momentumainak, ahol is ezen viszonyok, tapasztalatok és fölfogások jóval nagyobb felszínre terjednek ki, mint a hely, amelyet most esetlegesen definiálni óhajtunk." ${ }^{21}$

Noha a helyek/helységek globálisan és társadalmilag konstituálódnak, egy új lokalizmus esélyei korántsem illuzórikusak. ${ }^{22}$ A globális hálózat viszonyai közepette új közösségiség jön létre: egyfelól a virtuális térben - másfelól fizikálisan is, vagyis a helyiben.

${ }^{20}$ The New York Review of Books, 1985. jún. 13., 11. o.

${ }^{21}$ D. Massey: „A Global Sense of Place”. Marxism Today, 1991. júniusi szám, 28. o.

${ }^{22}$ Kitúnó megfigyelésck ehhez különösen Raimondo Strassoldónál. Ahogyan írja: „A posztmodernizmust... a lokalizmus újjáćledése fémjelzi. A lokalizmus az egyik lehetséges kiút a modernitásra jellemzó anómiából, elidegenedésból és azonosságvesztésból. Az Ưj Lokalizmus menedék keresését jelenti a tágabb világ nyugtalanító zavarai elól. [...] A posztmodern ember, éppen mivel olyannyira beágyazódott a globális információs áramlásokba, szükségét érezheti annak, hogy újjáélessze az ismerôsség, intimitás, biztonság, érthetốség, szerves-érzéki interakció kis enklávéit... Azáltal, hogy az egész világ könnyen, kevés idôvel és pénzzel elérhetô, új jelentést nyer az igény valamiféle szubjektív középpont - az otthon, a közösség, a hely - iránt, amelyból elindulhatunk, és amelyhez visszatérhetünk megpihenni. [...] A neolokalizmus... persze... eltér a régi lokalizmustól. Két lényegi különbségre mutathatunk rá. Az elsố: míg a régi lokalizmus »ôscredeti «, gondolattalan volt, az új szabad akarat, tudatos választás eredményc; clóbbi »szükségszerú és természetes “, utóbbi önkéntes és szándékolt (racionális). A második különbség: a régi lokalizmus arra irányult, hogy minimalizál- 
Tekintsük először a virtuális tartományt. Már jeleztük, hogy az e-mail kapcsolatoknak egyáltalán nem kell személytelennek lenniök. Egyszer s mindenkorra le kell söpörnünk az asztalról azt a mítoszt, miszerint a szenvedélyes hálózathasználó a valóságban remete vagy különc volna. Ellenkezóleg: minden tapasztalat azt bizonyítja, hogy az odaadó virtuális aktivitás együtt jár az odaadó valós emberi tevékenységgel. Másodszor belátható, hogy a hálózat lehetőséget kínál olyan közösségek létezésére, mint a legkülönbözóbb vallási vagy világi szubkultúrák, vagy etnikai csoportok létezése, amelyek egyébként egyáltalán nem, vagy csak nagy nehézségek árán és rossz hatásfokkal jöhetnének létre, illetve maradhatnának fenn. A hálózat a hátrányos helyzetú kultúrákat és kivált a kis nyelveket inkább védeni, mint elpusztítani látszik. Mint Geoffrey Nunberg írta a közelmúltban: „A minap egy félórás net-séta során több mint hatvan nyelven találtam vitacsoportokat - itt abbahagytam a számolást. [...] Ha az emberek választhatnak, az internetet szívesebben tekintik a ház elótti kispadnak, mint világfórumnak." ${ }^{23} \mathrm{~A}$ diaszpóra, a bevándorlók, az egymástól határokkal elválasztott kisebbségek - immár valamennyien intenzív virtuális kapcsolatban maradhatnak.

Egyetlen virtuális közösség sem rendelkezik ugyanakkor a valóságos közösségek kohéziós erejével. Gérard Raulet nyolcvanas évekbeli tanulmánya, „Az új utópia”, ${ }^{24}$ nagy nyomatékkal utalt a szimbolikus, ,interaktivitás” és a valóságos közösségi interakció közötti szakadékra. A virtuális kommunikáció valóságos alapokat elóföltételez: a McLuhan-i „globális falu” polgárainak végső soron tényleges közösségekhez is tartozniok kell. Ilyen közösségek, többek között, a lokális közösségek. Ha elismerjük is, hogy a lokalitások társadalmi konstrukciók: nem mondhatjuk-e ennek ellenére, hogy a hely, a fizikai territórium különleges a jelentőségư csoport és az egyes egyén életében? Hiszen a mindennapi élet fizikai kerete - részben - éppenséggel helyhez kötött; s csak tartós helyhez kötött erốfeszítések árán alkotható meg és tartható fenn. Épületek, utcák, csatornázás; a tó vízminốsége; a környék közbiztonsága; de a lakosság is - közelebbról az emberek, akiket ott ismerünk, akikkel találkozni szoktunk; a nyelv; s persze a saját történetünk, mely a hellyel összeköt. Viszonylagos stabilitások ezek a globálisan-társadalmilag mindig változónak a folyamában. Ilyen stabilitásokról van szó, amikor helyi közösségról és helyi politikáról beszélünk.

$\mathrm{S}$ most a második pont: a dokumentumok változatlanságának problémája. Ahhoz, hogy az információ tudásnak minôsülhessen, kontextusba kell illeszkednie. A személyes, face-to-face kommunikáció esetében ilyen kontextust nyújt a helyzet, amelybe a kommunikáció ágyazódik. Az írott s különösen a nyomtatott szövegek passzusait általában a tágabb szövegkörnyezet, adott esetben a teljes könyv adja, sốt olykor a könyvtár,

\footnotetext{
ja a külvilággal fenntartott kapcsolatokat, hogy crős zárt határvonalat húzzon, míg az új lokalizmus nagyon is tudatában van a világ egyéb részcinek, és nagyon is nyitott arra, hogy interakciókba lépjen azokkal.” (Strassoldo: „Globalism and Localism: Theoretical Reflections and Some Evi dence”. Lásd Zdravko Mlinar [szerk.]: Global ization and Territorial Identities. Aldershot, 1992, Ave bury, 46. sk. o.)

${ }^{23}$ The Economist, 1996. dec. 21., 48. o.

${ }^{24}$ G. Raulet: „Die neue Utopie. Die soziologische und philosophische Bedeutung der neuen Kommunikationstechnologien”. Lásd M. Frank, G. Raulet és W. van Reijen (szerk.): Die Frage nach dem Subjekt. Frankfurt/M., 1988. „[A]z új »kommunikációs « eszközök”, írja Raulet, „nem jelentik szükségképpen az egyéni és társadalmi identitások gazdagodását és megerôsítését..., hanem ki is válthatják azt..., amennyiben lebegő identitásokkal és anomikus viselkedésmódokkal járnak", 283. sk. o.
} 
amelynek állományához a könyv tartozik. A nyomtatott köny, ahogyan McLuhan szokta volt mondani, meghatározott nézópontot közvetít - szerzójének nézópontját. Ha könyvben olvasunk vagy szemelgetünk, ha a könyvtár polcai mentén sétálunk, vagy akár a katalógus cédulákat forgatjuk, valamiféle olyan helyzetérzékelésre teszünk szert, amely elektronikus közegben nem adódik. Ahhoz, hogy tudásunk bármiféle érte lemben teljes legyen, tudnunk kell, hogy mit tudunk, valamiféle áttekintéssel, memorizált vázlattal kell bírnunk tudásunkat illetốen. Fölidézzük az oldal képét a könyvben, vagy a kötet helyét a könyvtárban; emlékezetképünk van bizonyos fontos bekezdésekról. Amikor a szövegeket képernyơn olvassuk vagy futjuk át, ilyen áttekintésre aligha tehetünk szert. ${ }^{25}$

S itt van azután az idóbeliség kontextusa. A könyv vagy könyvek sora a könyvtár polcain, már puszta fizikai jegyeivel is megteremti azt. Ahogyan Sven Birkerts oly magávalragadóan írja: „múltérzékünk... valamiképpen lényegi módon reprezentáltatik a könyv által és a könyvtárakban a könyvek fizikai sokasodása által. Az egyes kötetnek, vagy a kötetek tömegének szemlélésével képet alkotunk magunknak az elmúlt idôról mint lerakódó rétegek egymásra épüléséról; valami mélységet és dimenzionalitást ragadva meg ezzel." 26

Miközben a könyvek a szoliditás, a szilárdság érzését sugallják, az elektronikus szövegek cseppfolyósak, illékonyak. Amiképpen a beszéd, általánosságban, kevésbé koherens, mint az írás, úgy a képernyốn fogalmazott szöveg is kevésbé koherens, mint a kézírásban vagy az írógépen fogalmazott. Ennek oka világos. A koherencia megórzése azt feltételezi, hogy szövegeket összehasonlítunk egymással, vagy hogy a szöveg egyik részletét összehasonlítjuk ugyanannak a szövegnek másik részletével. A képernyốn ilyen összehasonlítások csak nagyon korlátozott mértékben végezhetók el. Az elérhetố és releváns dokumentumoknak vagy akár csak egyetlen hosszabb dokumentumnak szinoptikus szemlélete nem lehetséges. Az ellentmondások nehezen fedezhetók föl; a szöveg egysége nehezen tartható fönn. A logikai szigorúság csökkenése óhatatlan következmény. A digitális szövegfeldolgozás világában létrejövő gondolkodás cseppfolyós, töredezett, a nézôpont elillanó egysége által jellemzett. A networking elterjedésével a problémák csak mélyülnek.

A harmadik ponthoz érkezem, szeretnék itt azonban egy megjegyzést közbevetni. Fentebb annak a szükségességéról beszéltünk, hogy valódi lokalitásokhoz, helyekhez tartozzunk; most pedig annak a szükségességéról, hogy ne adjuk fel a nyomtatott könyvek világát. A könyvnyomtatás egyik leglényegesebb következménye a nemzeti nyelvek kialakulása volt, a nemzeti territoriális elvnek viszont, a politikai szerveződés szintjén, éppenséggel az állami elv felel meg. ${ }^{27}$ A konzervatív korollárium, amelyhez ezzel, meglepő módon jutottunk: a globális számítógépes hálózottságnak nem szabad aláásnia a nemzetállam intézményét. ${ }^{28}$

\footnotetext{
${ }^{25}$ Részletesebben írtam erról „Hálózat és tudásegćsz” címû tanulmányomban, lásd Sándor I. és munkatársai (szerk.): A századvég szellemi körképe. Pécs, 1995, Jelenkor Kiadó, 117-135. o.

${ }^{26}$ Sven Birkerts: The Gutenberg Elegies: The Fate of Reading in an Electronic Age. Boston, 1994, Faber and Faber, 129. o.

${ }^{27}$ Vö. pl. Michael Mann: „The Autonomous Power of the State: Its Origins, Mechanisms and Results”. Lásd John A. Hall (szerk.): States in His to ry. Oxford, 1986, Basil Blackwell.

${ }^{28}$ Idézzünk itt egy részt Helmut Schmidt: Globalisierung: Politische, ökonomische und kul tu relle Herausforderungen címú könyvéból: „Sajnos szükségszerûnek látszik számomra, hogy a globalizációnak a gazdaság-
} 
A harmadik pont tehát, rövidebben, mint szükséges volna: az emberi kapcsolatok állandóságának problémája. Utaltam már Raulet a virtuális interaktivitást a tényleges társadalmi interakcióval szembeállító elemzésére. Idézzük fel továbbá empirikus vizsgálatok imponáló skálájának ama lényegében konzisztens eredményeit, melyek értelmében a telekommunikációnak, bármily súrúek és sokdimenziójúak legyenek is a hálózatok, nincsen meg az a kognitív hatékonysága - az érzelmi hatásról már nem is beszélve -, mint a személyes találkozásoknak. ${ }^{29}$ Annak idején megállapították, hogy noha olyankor, amikor más kapcsolatra nem volt lehetőség, a telefonkapcsolatok nagyon is számítottak, ${ }^{30}$ de ezeknek, szemben a személyes találkozásokkal, csekély erejük volt üj kapcsolatok teremtésére. A telefonkapcsolatok akkor hatékonyak, ha korábbi személyes találkozások háttér-információira támaszkodhatnak, s ha ilyen találkozások révén rendszeres megerôsítést nyernek. ${ }^{31}$ Ugyanez a minta marad érvényes az e-mail és a telekonferencia megjelenésével. ${ }^{32}$ A videokonferenciák hatékonysága csekély, ha hátterükben nem állnak tényleges összejövetelek; az e-mail levelezés abbamarad, ha nem egészül ki személyes találkozásokkal, vagy ha legalább telefonhívások és/vagy videokapcsolatok nem élénkítik.

Összefoglalom a mondottakat. A funkcionális konzervativizmus megórzésre törekszik annak érdekében, hogy bizonyos kívánatosnak tartott változások valóban a kívánatosnak tartott irányba vezessenek. A globalizáció által elvben lehetôvé tett gazdasági racionalitás és ideológiai nyitottság, és kivált a globális információs társadalom kommunikációs közege - vagyis az internet -által kilátásba helyezett multimediális tu-

ban és a tudományban, az interneten és a televízióban, az amerikai angol - úgy is mondhatnánk: az amerikaiasra satnyult angol - dominanciájához kell vezetnie. Aki az amerikai globális dominanciája ellen védekezni akar - akár csak a maga nyelvének megốrzése okán - , az kudarcot fog vallani. Mindazonáltal ki-ki nyelvi hagyományainak megôrzése nem kevesebbet, mint a túlélést szolgálja. Mert ha a magunk nyelve elsüllyed, vagy néhány nemzedék alatt teljesen tönkremegy, akkor a kultúránk tetemes része is elvész - és akkor részben az identitásunk is elvész. De ennek nem kell szükségképpen így történnie” (DVA, 1998, 126. sk. o.).

${ }^{29}$ Úttörô tanulmány ehhez Richard L. Meier: A Communications Theory of Urban Growth. Cambridge, MA, 1962, MIT Press.

${ }^{30}$ Vö. pl. Suzanne Keller: „The Telephone in New (and Old) Communities”. Lásd Ithiel de Sola Pool (szerk.): The Social Impact of the Telephone. Cambridge, MA, 1977, MIT Press.

${ }^{31}$ Vö. kül. Bertil Thorngren: „Silent Actors: Communication Networks for Development”. Lásd Ithiel de Sola Pool (szerk.): The Social Impact of the Telephone.

${ }^{32}$ A telekommunikációnak a városi és regionális fejlôdésre gyakorolt hatását elemezve, Lionel Nicol 1985-ben így fogalmazott: „A telekommunikációról - már a telefonról is - hagyományosan azt mondják, hogy decentralizáló befolyása van. Az alapvető érv úgy szól, hogy a jobb kommunikáció csökkenti a tér ellenállását, vagyis azokat a surlódási cróket, amelyeket a földrajzi tér támaszt a személyek, áruk és információk mozgásával szemben. [...] Ám nem mutatkozik jele annak, hogy - imponáló clónyeinek dacára - a telekommunikáció kiszorítaná a szállítást... Az ezzcl ellentétes állítások egyszerúen figyelmen kívül hagyják ama körülményt, hogy a jobb kommunikáció folytán egyszersmind nô az igény az intézményes vagy kulturális okokból on-line nem létesíthetô-fenntartható személyes kapcsolatok iránt.” (Lioncl Nicol: „Communications Technology: Economic and Spatial Impacts”. Lásd Manuel Castells (szerk.): High Technology, Space, and Society. Beverly Hills, CA, 1985, Sage, 195. o.) Ahogyan Mitchell L. Moss írta: „Noha számos úgynevezett jövókutató hangoztatja, hogy az elektronikus kunyhó fel fogja váltani az irodaépületet, s hogy a telekonferencia fel fogja váltani a személyes találkozókat, az ilyen spekuláció mindösssze a város funkcióinak elégtelen megértéséról tanúskodik... ...a telekommunikáció nem csökkentette a nagy városi központokban történố személyes tranzakciók értékét.” (Mitchell L. Moss: „Telecommunications and the Future of Cities”. Land Development Studies, 3 [1986], 38. sk. o.) 
dásgazdagság üres ígéretté válhat, ha fizikai, kognitív és emberi környezetünk nem rendelkezik a specifikus stabilitások valamiféle minimumával. Az ilyen stabilitások megốrzése melletti kiállás értelmes és realisztikus konzervatív program. Képesek vagyunk arra, hogy valahol állandó otthont rendezzünk be magunknak, hogy szomszédságunk ügyei iránt érdeklődést tanúsítsunk, hogy részt vegyünk a helyi erôfeszítésekben - a helyi múvelődést elősegítő erőfeszítésekben is, kivált azokban, amelyek az adott helységet a globális hálózatokhoz kötnék. Képesek vagyunk arra, hogy a magunk intellektuális tevékenysége során a digitális közeg és különösen a networking vonatkozásában elsajátított készségeinket a könyvek iránti elkötelezettséggel ${ }^{33}$ kapcsoljuk össze, s hogy ragaszkodjunk a printout funkcióhoz és a hardcopy példányokhoz. Képesek vagyunk arra, hogy a magunk szellemi környezetében fenntartsuk valamiféle irodalmi kánon eszméjét - a „lokális kánonok” eszméjét, Fowler szerencsés megfogalmazásában, ${ }^{34}$ vagy a „miniatürizált tradíciókét”, amint azt Bolter kevésbé találóan kifejezi. ${ }^{35}$ És képesek vagyunk arra, hogy egyfajta egyensúlyra törekedjünk virtuális és valóságos találkozásaink között, sốt arra is, hogy utóbbiakat nem ritkán hasznos, tartalmas és állandó ismeretségekké formáljuk.

${ }^{33}$ Ebben az értelemben beszél Helmut Schmidt arról, hogy „,a globalizáció korában” önnön nyelvi örökségünk megốrzése „a személyes kritikus ítélóképesség s az egyéni öntudat” fenntartásának elengedhetetlen föltétele. (Helmut Schmidt: Globalisierung: Politische, ökonomische und kulturelle Herausforderungen, 122. sk. o.)

${ }^{34}$ Robert M. Fowler: „The Fate of the Notion of Canon in the Electronic Age” (1994), Forum, 9 (1993), 151-172. o., elektronikus formában lásd: <http://homepages.bw.edu/ rfowler/pubs/canon/index.html>.

35 „Pozitív módon is tekinthetünk kultúránk állandó magjának elvesztésére. Noha elveszítjük a koherens kulturális tradícióhoz tartozás megelégedett érzését, annak szabadságát nyerjük, hogy megteremthetjük a magunk miniatürizált tradícióit." (Jay David Bolter: Writing Space: The Computer; Hy per text, and the History of Writing. Hills dale, N. J., 1991, Lawrence Erlbaum Associates, 238. o.) 